\title{
Local Residents' Attitude toward Sustainable Rural Tourism Development
}

\author{
Iulia C. Muresan 1,*, Camelia F. Oroian ${ }^{1}$, Rezhen Harun 2,*, Felix H. Arion 1,*, Andra Porutiu ${ }^{1}$, \\ Gabriela O. Chiciudean ${ }^{1}$, Alexandru Todea ${ }^{1}$ and Ramona Lile ${ }^{3}$
}

Received: 16 November 2015; Accepted: 19 January 2016; Published: 21 January 2016

Academic Editor: Marc A. Rosen

1 Department of Economic Sciences, University of Agricultural Sciences and Veterinary Medicine Cluj-Napoca, 3-5 Manastur Street, Cluj-Napoca 400372, Romania; cameliatodoranusamv@gmail.com (C.F.O.); andra.porutiu@usamvcluj.ro (A.P.); gabriela_chirla@yahoo.com (G.O.C.); alexandru.todea@usamvcluj.ro (A.T.)

2 Department of Agribusiness and Rural Development, Faculty of Agricultural Sciences, University of Sulaimani, Kurdistan Regional Government-Iraq, Sulaimani-Bakrajo 5100, Iraq

3 Department of Economics, Faculty of Economic Sciences, "Aurel Vlaicu” University of Arad, 77 Bdul. Revolutiei, Arad 310130, Romania; ramonalile@yahoo.com

* Correspondence: iulia.muresan@usamvcluj.ro (I.C.M.); rezhen.rashid@univsul.edu.iq (R.H.); felixarion@usamvcluj.ro (F.H.A.); Tel.: +40-721-643-136 (I.C.M.)

\begin{abstract}
Tourism is a multi-faced activity that links the economic, social and environmental components of sustainability. This research analyzes rural residents' perceptions of the impact of tourism development and examines the factors that influence the support for sustainable tourism development in the region of Nord-Vest in Romania. Residents' perceptions towards tourism development were measured using 22 items, while their support for tourism development was determined using 8 items. Descriptive and inferential statistics were used to analyze the data. Principal component analysis grouped the first 22 variables into 4 factors, and the following 8 variables into 2 factors (sustainable development, destination development). Findings indicate that residents see tourism as a development factor. The natural, economic, and social-cultural environment as well as infrastructure, age, gender and education are factors that influence the sustainable development of tourism.
\end{abstract}

Keywords: rural tourism; tourism planning; residents' attitudes; tourism impact

\section{Introduction}

The importance of tourism nowadays is determined by the multiple roles that it plays within any country (economic, social and cultural) and its ability to create a positive impact (employment, wealth, dynamism, income enhancement, infrastructure, international friendship and moving people and assets) [1,2]. The tourism sector has become, during the last several decades, a major factor of importance in world GDP because of its rapid growth and development [3,4], often associated with an export industry [5]. Eshliki and Kaboudi [6] describe the tourism sector as a "powerful force of change in the economy," mainly due to its positive economic impact on communities. Stetic [7] underlines the key role that rural areas play in the tourism sector, not only because of their special position as areas of excellence, but also as ecological oases combined with the ability to preserve traditional culture and ethno-cultural heritage. Therefore, Vazques et al. [8] appreciate the importance of rural tourism as a key factor for proper socio-economic development, while Giannakis [9] highlights the importance of rural areas within the European Union from the point of view of their vast territory held (91\%) and the population involved (59\%). These rural areas can be strengthened and revitalized 
only through proper and viable tourism based on sustainable development [10]. Because of the high importance of the tourism sector, the newest Tourism Action Framework at the European level mentions among its main priorities the stimulation of long-term competitiveness and the promotion of sustainable development [11]. The main advantages of the sustainable approach in tourism are related to good practices and improvements, especially regarding the environment; however, at the same time, the concepts' incapacity for a proper implementation in practice has been observed [12]. Either way, sustainable tourism development is strongly related to local communities and their attitudes towards tourism. Within the process of developing a sustainable tourism sector, the local community is the key element, as it is directly affected by its evolution [6].

Development of tourism influences the development of other sectors such as agriculture, food processing and handcrafting, which can contribute to the well-being of the entire community. Previous studies about Romanian rural tourism analyzed the factors that influence rural tourism development $[13,14]$, the particularities of rural tourism potential $[15,16]]$, supply $[17,18]$ and demand $[17,19]$. Local residents represent an important component of the amalgam that constitutes the destination [20] and influences the future development of any tourism destination.

The aim of this paper is to identify the support of the local community towards sustainable tourism development in the region of Nord-Vest in Romania. To this end, residents' perceptions towards the impact of tourism development are identified, and, secondly, the residents' support for future tourism development is determined. The analysis reveals that the support for future tourism development is based on two components: sustainable development and destination development. In this context, the paper presents an original approach towards the subject, the results of which can be useful in creating future development strategies.

\section{Literature Review}

The idea of sustainable tourism development emerged in the last several decades as a necessity to ensure an efficient tourism sector based on three main components: environmental interests, socio-cultural and economic needs of the communities involved [21]. To maintain a balance between the positive and negative impacts that the three factors could generate, one must take into consideration the local community-the core element within the tourism development process and the most important stakeholder [22-24]. Analyzing the local community's perceptions regarding tourism impact becomes a major concern, because it is strongly connected to the will to support tourism development $[25,26]$. Generally, tourism is perceived by residents as having strong economic benefits, which outweigh any other possible negative impacts, encouraging residents to perceive tourist activity in a positive way and resulting in strong involvement and support $[26,27]$. Still, interesting findings were noted in Vietnam, where touristic activity is supported by the community not for its economic benefits, but rather for its socio-cultural and environmental benefits [28].

Studies focus both on the negative and positive impacts of tourism on local communities. For example, communities in Egypt have been shown to support tourist activity, even if both negative and positive impacts are perceived, because the positive are stronger than the negative [3]. In terms of economic development, positive impacts are reflected in job creation, investments and increasing the national income, while negative impacts are related to an increased level of inflation. Socio-cultural factors can generate two kinds of attitudes: positive ones related to cultural exchange, and negative ones linked to the way of life and overcrowded places [3]. In research conducted in Arizona, Mcgehee and Andereck [27] concluded that support for tourism development is highly related to personal benefits obtained by the local community members, where overall the community perceives tourism in a positive way due to its effects on the local economy (such as job creation and an improvement in quality of life). A study conducted in Mauritius observed a similar positive economic impact due to job creation and improvements in quality of life. A positive relationship was observed between the support for tourism and economic and socio-cultural factors, while a negative relationship was established between community support and the environment [5]. 
It has been observed that the main components of sustainable tourism development influence the local community's goodwill and support for tourism; therefore, much research focuses on studying its economic, environmental and socio-cultural impacts $[3,5,22,27,29,30]$. Even if tourism offers important positive benefits, its strong development could cause major dissatisfaction among communities due to intensive traffic, inflation, and crime [6,29].

The relationship between community satisfaction and tourism development analyzed by Min et al. (2012) [22] shows that, even if the level of satisfaction related to tourist activity in the area is not high, the community still supports it when it is considered promising for future city development. The residents' support for tourist activity is connected also to their perceptions of economic, environmental and socio-cultural factors. Positive impact on aforementioned factors indicate high support from the local community [23,30,31].

An important finding was obtained by Koa and Stewart [29] after conducting a study in the Keju Islands of Korea, a relatively undeveloped area. Results indicated that residents' attitudes toward tourism are directly related to the stage of development of the host community. In Uganda it was observed that the local community has a positive attitude towards tourism because it is considered as a factor of development generating incomes, increasing agricultural production and "good fortune" [32]. The results of research conducted in North Carolina indicated two main reasons for which the community is willing to support tourist activities, which are strongly related to the personal benefits obtained: The female population positively perceives the cultural dimension represented by the development of arts, craft and household items, while the youngsters perceive improvements in social life and recreation facilities [33]. The community attachment and involvement, as well as the support for sustainable tourism development, are influenced by their perceived benefits to local residents [34]. Understanding the residents' perceptions towards tourism is important in order to shape future policies that minimize the potential negative impact of tourism and maximize its benefits [35].

\section{Materials and Methods}

The study was conducted in a rural area in the region of Nord-Vest in Romania from November 2014 to April 2015. Nord-Vest comprises 6 counties: Bihor, Bistrita-Nasaud, Cluj, Maramures, Satu-Mare and Salaj. It has a surface area of $34,159 \mathrm{~km}^{2}$, representing $14.32 \%$ of the total country surface. The region borders both Hungary and Ukraine [36].

This region has a high potential for tourism due to its natural environment and landscape (mountains, natural reservations, thermal waters, salt mines) and to a variety of cultural tourist attractions (churches, wooden churches, traditions, etc.). The region includes 170 protected areas of national importance, of which two are national parks (Rodna Mountains National Park and Calimani National Park) and two natural parks (Apuseni Natural Park and Maramures Mountains Natural Park) [37]. The parks, both national and natural, attract tourists due to the possibilities of hiking, bird watching, rural tourism and agritourism [38,39].

Table 1 presents a timeline of tourism's supply and demand from 2005 to 2014. In Nord-Vest, at the end of 2014, there were 676 (11\% of the total number at national level) lodging facilities, of which $33 \%$ (226) were agritourism guesthouses, which represent the main type of accommodation facility in the rural area. During the last 10 years in Nord-Vest, the number of lodgings rose by $40 \%$ and the number of agritourism guesthouses $61 \%$, while the occupancy rate and the average length of stay remained quite similar. This can be explained by the increase in the number of tourist arrivals and overnight stays. The arrivals in agritourism guesthouses in the region of Nord-Vest increased by almost 200\%, and the overnight stays by 188\% from 2005 to 2014 . The number of guesthouses increased from 2005 to 2010 by $90 \%$ mainly due to European funds that supported rural development, and by the end of 2014 they decreased by $15 \%$. Factors which could have led to this decreasing trend may include managers' lack of specific entrepreneurial education and skills [40], and owners' lack of capacity to adapt and diversify their services according to the needs of the tourists [41]. The majority of the guesthouses assure basic facilities (bed \& breakfast); in this case, it can be stated that Romanian rural tourism lacks 
additional touristic services for entertainment, outdoor and indoor recreation, handicrafts and other souvenirs [42].

Table 1. Evolution of tourist activity indicators in Romania and North-West Region.

\begin{tabular}{|c|c|c|c|c|c|c|c|c|c|c|c|}
\hline \multirow{2}{*}{ Region } & \multirow{2}{*}{ Indicator } & \multicolumn{10}{|c|}{ Year } \\
\hline & & 2005 & 2006 & 2007 & 2008 & 2009 & 2010 & 2011 & 2012 & 2013 & 2014 \\
\hline \multirow{6}{*}{ Romania } & Number of lodgings & 4226 & 4710 & 4694 & 4840 & 5095 & 5222 & 5003 & 5821 & 6009 & 6130 \\
\hline & Number guest houses & 956 & 1259 & 1292 & 1348 & 1412 & 1354 & 1210 & 1569 & 1598 & 1665 \\
\hline & $\begin{array}{l}\text { Total average length of } \\
\text { stay (nights)* }\end{array}$ & 3.16 & 3.06 & 2.95 & 2.91 & 2.82 & 2.64 & 2.56 & 2.49 & 2.44 & 2.40 \\
\hline & $\begin{array}{l}\text { Guesthouses average } \\
\text { length of stay (nights)* }\end{array}$ & 2.15 & 2.12 & 2.05 & 2.08 & 2.07 & 2.09 & 2.06 & 2.03 & 1.99 & 1.97 \\
\hline & Total occupancy rate $(\%)$ * & 33.42 & 33.61 & 36.04 & 35.02 & 28.35 & 25.16 & 26.28 & 25.85 & 25.14 & 26.11 \\
\hline & $\begin{array}{l}\text { Guest houses occupancy } \\
\text { rate }(\%) *\end{array}$ & 14.47 & 14.41 & 16.34 & 18.41 & 14.22 & 12.36 & 13.78 & 13.20 & 12.56 & 13.16 \\
\hline \multirow{6}{*}{ Northwest } & Number of lodgings & 480 & 543 & 554 & 585 & 645 & 658 & 650 & 730 & 709 & 676 \\
\hline & Number guest houses & 140 & 193 & 200 & 225 & 259 & 266 & 206 & 252 & 231 & 226 \\
\hline & $\begin{array}{l}\text { Total average length of } \\
\text { stay (nights)* }\end{array}$ & 3.12 & 3.03 & 2.87 & 2.79 & 2.87 & 2.68 & 2.61 & 2.48 & 2.35 & 2.35 \\
\hline & $\begin{array}{l}\text { Guesthouses average } \\
\text { length of stay (nights) * }\end{array}$ & 1.99 & 1.98 & 1.92 & 1.95 & 1.93 & 1.98 & 2.04 & 2.03 & 1.92 & 1.92 \\
\hline & Total occupancy rate $(\%)^{*}$ & 32.24 & 32.06 & 34.05 & 32.69 & 27.70 & 23.25 & 23.61 & 22.33 & 22.58 & 25.38 \\
\hline & $\begin{array}{l}\text { Guest houses occupancy } \\
\text { rate }(\%) *\end{array}$ & 13.16 & 15.17 & 19.74 & 24.22 & 14.52 & 9.35 & 9.77 & 10.76 & 10.95 & 13.15 \\
\hline
\end{tabular}

Source: National Institute of Statistics, Tempo-online time-series [43]; ${ }^{*}$ compute based on data from National Institute of Statistics.

To examine residents' perceptions towards the impact of tourism development in Nord-Vest, the authors used a quantitative survey. The collected data can be divided into three main sections: perception of tourism impact, support of tourism development and socio-demographic characteristics of the respondents. The 22 variables used to determine the rural residents' perceptions of tourism development were adopted from previous studies $[3,5,6,27,29,33,44-47]$. The support for tourism development was measured with 8 variables developed by [47,48]. A 5-point Likert-type scale was used based on the following scale: $1=$ strongly disagree, $2=$ disagree, $3=$ neutral, $4=$ agree, 5 = strongly agree to evaluate each variable.

Data were collected from 433 residents from the rural area of Nord-Vest. The sample size was determined based on the following formula [30].

$$
n=\frac{(1.96)^{2} \times 1075725 \times 0.5 \times(1-0.5)}{(0.05)^{2} \times(1075725-1)+(1.96)^{2} \times 0.5 \times(1-0.5)}=400 \text { residents }
$$

550 questionnaires were distributed to a proportional stratified random sample of adults. The response rate was 91\% (502 questionnaires), and in the end 433 questionnaires were validated.

The selection of the respondents was based on their age respective of the distribution of the original population.

Descriptive statistics were used to determine the socio-demographic profile of the rural residents and to describe the rural residents' perceptions of tourism development as well as their support for it. Exploratory factor analysis was used to assess the factor structure of the variables. Principal component analysis (PCA) is a data reduction method in which the components are calculated using all of the variance of the manifest variables, with all of that variance appearing in the solution [49]. This is achieved by transforming a new set of variables, which are uncorrelated, and which are ordered so that the first few explain most of the variance [50]. Mathematically, this is equivalent to finding the best low rank approximation of the data via the singular value decomposition [51]. 
Two principal component analyses were conducted separately, the first to group the perception variables about tourism development, and the second to group the variables regarding future tourism development support. The varimax rotation was used to maximize the differences among the components extracted and to maintain correlation among the components. A simple correlation analysis (Spearman rank-order correlation coefficient) was utilized to calculate the correlation between the support for sustainable tourism development and the impact of tourism, and between the support for tourism destination development and the impact of tourism development.

\section{Results and Discussion}

\subsection{Rural Residents' Characteristics}

The socio-demographic characteristics of the respondents are presented in Table 2. According to the National Institute of Statistics, at the end of the year 2014, 57\% of people from rural areas were more than 40 years old. This data is reaffirmed by the results of the current study. The results can mainly be attributed to the lack of attractive employment opportunities in the rural area for the younger generation. Another problem in the rural area is the low level of education. Most of the respondents had graduated from high school (45.4\%), while $28 \%$ had less than high school education. The monthly household income levels reported are less than 225 Euro (36.4\%), 225-445 Euro (36\%), more than 445 Euro $(27 \%)$, while the average family number is 3.7 members. It can be concluded that the rural population was aging and less educated, with a low monthly income.

Table 2. Characteristics of the respondents.

\begin{tabular}{|c|c|}
\hline Variables & $\%$ \\
\hline \multicolumn{2}{|c|}{ Gender } \\
\hline Female & 41.57 \\
\hline Male & 58.43 \\
\hline \multicolumn{2}{|c|}{ Age } \\
\hline $15-19$ & 1.20 \\
\hline $20-29$ & 18.2 \\
\hline $30-39$ & 24.1 \\
\hline $40-49$ & 28.8 \\
\hline $50-59$ & 19.6 \\
\hline$>60$ & 8.00 \\
\hline \multicolumn{2}{|c|}{ Education } \\
\hline Illiterate & 0.20 \\
\hline Less than high school & 28.1 \\
\hline High school & 45.4 \\
\hline University & 26.2 \\
\hline \multicolumn{2}{|c|}{ House hold income } \\
\hline$<225$ euro & 36.4 \\
\hline 225-445 euro & 35.9 \\
\hline$>445$ euro & 27.7 \\
\hline
\end{tabular}

\subsection{Factors of Rural Residents' Perception towards Tourism Development}

Principal factor analysis was conducted to assess the dimensionality of the 22 items. The Barlett test of sphericity is significant (Chi-square $=3915.62, p<0.000)$. The Kaiser-Meyer-Olkin $(K M O)$ overall measure of sampling is 0.88 , indicating that data are suitable for the principal component analysis [52]. Values of 0.6 or above from the KMO measures indicated that data are adequate for PCA [53]. The PCA with varimax rotation of the 22 variables resulted in a four-component solution that explains $57.66 \%$ of the total variance. Only factors with eigenvalues greater than one were selected [54]. Cronbach's alpha reliability coefficient was computed to evaluate the internal consistency of each component. 
An acceptable reliability coefficient is higher than 0.6 [54-56]. The overall reliability of the 22 variables was 0.87 .

The components recorded after the first principal component analysis are listed in Table 3. Component 1 comprises 8 variables ( 0.87 alpha), component 2 comprises 6 variables ( 0.82 alpha), component 3 comprises 5 variables ( 0.73 alpha), and component 4 comprises 3 variables ( 0.67 alpha).

Table 3. Principal component analysis on tourism impact variables.

\begin{tabular}{|c|c|c|c|c|c|}
\hline Eigenvalue & Variance \% & Component & Item & $\begin{array}{l}\text { Factor } \\
\text { Loading }\end{array}$ & Communalities \\
\hline \multirow{8}{*}{6.10} & \multirow{8}{*}{27.74} & \multirow{8}{*}{$\begin{array}{l}\text { Environmental } \\
\alpha=0.87\end{array}$} & $\begin{array}{l}\text { Development of tourism damage } \\
\text { natural environment and landscape }\end{array}$ & 0.793 & 0.632 \\
\hline & & & $\begin{array}{l}\text { Tourism cause overcrowding problems } \\
\text { for residents }\end{array}$ & 0.777 & 0.661 \\
\hline & & & Tourism increase the air pollution & 0.775 & 0.641 \\
\hline & & & Tourists use too much water & 0.770 & 0.598 \\
\hline & & & Tourism results in more litter in an area & 0.739 & 0.571 \\
\hline & & & $\begin{array}{l}\text { Tourism development negatively } \\
\text { affects the recreational facilities and } \\
\text { entertainment }\end{array}$ & 0.690 & 0.537 \\
\hline & & & $\begin{array}{l}\text { The construction of tourist facilities } \\
\text { destroy the environment }\end{array}$ & 0.674 & 0.461 \\
\hline & & & Increase traffic problems & 0.561 & 0.490 \\
\hline \multirow{7}{*}{3.67} & \multirow{7}{*}{16.68} & \multirow{7}{*}{$\begin{array}{l}\text { Economical } \\
\alpha=0.82\end{array}$} & $\begin{array}{l}\text { Tourism plays an important role in the } \\
\text { economic development of the area }\end{array}$ & 0.824 & 0.696 \\
\hline & & & $\begin{array}{l}\text { Tourism improves locals standard of } \\
\text { living }\end{array}$ & 0.802 & 0.735 \\
\hline & & & $\begin{array}{l}\text { Tourism increases a community's tax } \\
\text { revenue }\end{array}$ & 0.699 & 0.557 \\
\hline & & & Tourism create new jobs for locals & 0.649 & 0.562 \\
\hline & & & Tourism diversifies the rural economy & 0.546 & 0.502 \\
\hline & & & $\begin{array}{l}\text { Tourism results in an increase in the } \\
\text { cost of living }\end{array}$ & 0.540 & 0.624 \\
\hline & & & $\begin{array}{l}\text { Revenue from tourism taxes activity } \\
\text { should be invested in future } \\
\text { development of tourism }\end{array}$ & 0.523 & 0.386 \\
\hline \multirow{4}{*}{1.88} & \multirow{4}{*}{8.56} & \multirow{4}{*}{$\begin{array}{l}\text { Social and } \\
\text { Cultural } \\
\alpha=0.73\end{array}$} & $\begin{array}{l}\text { Tourism provide incentives for } \\
\text { restoration of traditional houses }\end{array}$ & 0.781 & 0.639 \\
\hline & & & $\begin{array}{l}\text { Interaction with tourists is a positive } \\
\text { experience }\end{array}$ & 0.776 & 0.617 \\
\hline & & & $\begin{array}{l}\text { Shopping and restaurants option is } \\
\text { better as a result of tourism }\end{array}$ & 0.676 & 0.552 \\
\hline & & & $\begin{array}{l}\text { Tourism development enhance more } \\
\text { recreational opportunities for locals }\end{array}$ & 0.431 & 0.468 \\
\hline \multirow{3}{*}{1.03} & \multirow{3}{*}{4.67} & \multirow{3}{*}{$\begin{array}{l}\text { Infrastructure } \\
\quad \alpha=0.67\end{array}$} & Improves traffic network & 0.798 & 0.693 \\
\hline & & & $\begin{array}{l}\text { Improves living utilities infrastructure } \\
\text { (supply of water. sewage. electric etc.) }\end{array}$ & 0.711 & 0.583 \\
\hline & & & Quality of public services in better & 0.508 & 0.480 \\
\hline $\begin{array}{c}\text { Total } \\
\text { variance } \%\end{array}$ & 57.66 & & & & \\
\hline
\end{tabular}


The first component labeled "environmental effects" explains $27.74 \%$ of the variance and has a mean of $2.58(\mathrm{SD}=1.049)$. This component involves attributes that focus on conservation of natural resources and negative impacts of tourism on the environment. The environmental effects are seen as being the most negative for the rural residents in terms of tourism development, such as destroying the natural environment (factor loading 0.793 ), overcrowding problems (factor loading 0.777 ), air pollution (factor loading 0.775), and water scarcity (0.770). The second component labeled "economic benefits" explains $16.68 \%$ of the variance and has a mean of $3.40(\mathrm{SD}=0.913)$. This component involves attributes related to the overall economic development (factor loading 0.824), tax revenue (factor loading 0.699), employment (factor loading 0.649), and living cost (factor loading 0.540). The third component labeled "social and cultural impacts" involves attributes related to quality of life and cultural activities. It explains $8.56 \%$ of the variance and has a mean of $3.50(\mathrm{SD}=1.008)$. This component groups items related to restoration of traditional houses (factor loading 0.781), diversification of recreational facilities (factor loading 0.431), alternative possibilities for shopping and dining (factor loading 0.676), and the perception of residents' interaction with tourists (factor loading 0.776). The fourth component explains $4.67 \%$ of the variance and involves attributes related to infrastructure development, being labeled "infrastructure benefits"; the mean is $3.19(\mathrm{SD}=1.100)$ (Tables 3 and 4). These results diverge from previous research, which has shown either that economic impacts may be more important [46,47], or that the social and cultural impacts were more significant [5] than the environmental component.

Table 4. Perception on tourism development impact.

\begin{tabular}{lcc}
\hline \multicolumn{1}{c}{ Item } & Mean & SD \\
\hline Environment & 2.58 & 1.049 \\
Damage natural environment and landscape & 2.45 & 1.393 \\
Tourism cause overcrowding problems for residents & 2.61 & 1.487 \\
Tourism increase the air pollution & 2.52 & 1.446 \\
Tourists use too much water & 2.33 & 1.398 \\
Tourism results in more litter in an area & 3.02 & 1.490 \\
Tourism development negatively affects the recreational facilities and entertainment & 2.60 & 1.463 \\
The construction of tourist facilities destroy the environment & 2.47 & 1.360 \\
Increase traffic problems & 2.69 & 1.412 \\
\hline Economic & 3.40 & 0.913 \\
Tourism plays an important role in the economic development of the area & 3.78 & 1.235 \\
Tourism improves locals standard of living & 3.31 \\
Tourism increases a community's tax revenue & 3.73 \\
Tourism create new jobs for locals & 3.290 \\
Tourism results in an increase in the cost of living & 1.294 \\
Tourism diversifies the rural economy & 1.435 \\
Revenue from tourism taxes activity should be invested in future development of tourism & 2.92 \\
\hline Social and Cultural & 2.97 & 1.391 \\
Tourism provide incentives for restoration of traditional houses & 1.323 \\
Interaction with tourists is a positive experience & 1.158 \\
Shopping and restaurants option is better as a result of tourism & 3.5 \\
Tourism development enhance more recreational opportunities for locals & 3.35 \\
\hline Physical & 3.58 & 1.008 \\
Improves traffic network & 1.488 \\
Improves living utilities infrastructure (supply of water, sewage, electric etc.) & 3.44 & 1.321 \\
Quality of public services in better & 3.62 & 1.197 \\
\hline & 3.19 & 1.100 \\
\hline
\end{tabular}




\subsection{Local Residents' Perception towards Tourism Development Impacts}

The host community tends to agree that development of tourism has a positive impact on the development of the region. The effects of tourism development on the natural environment and landscape are not perceived as being negative. The mean value of component 1 is 2.58 , lower than the one found in a similar study [5]. The only variable with a higher score than 3 is the one related to the quantity of litter in the area.

The rural residents believe that the revenue from the taxation of touristic activity should be used for the future development of this sector (mean = 4.09), since an increase in the community's tax revenue is perceived (mean $=3.73$ ). Tourism is seen as an important factor for the economic development of the area (mean $=3.78)$, which improves local standard of living (mean $=3.31$ ) without affecting the cost of living (mean $=2.92$ ). The findings support past studies regarding the people's perception towards the economic impact of tourism $[27,46,47]$. At the same time, it should be underlined that, for the rural residents of Nord-Vest, tourism is not perceived as an alternative to agricultural activities, nor as a factor of economic activities' diversification (mean $=2.97$ ). One of the causes may be the lack of knowledge regarding the founding sources and the fear of business failure [40].

The rural residents agree that the development of tourism in their region provides more recreational opportunities (mean $=3.62$ ), and interaction with the tourists is perceived as a positive experience $($ mean $=3.58$ ). The rural residents perceive the development of tourism as a factor that provides cultural identity and improves the quality of services, and, indirectly, the standard of living. These results confirm the findings of previous studies [46,47]. Tourism leads to the restoration and preservation of the cultural values of the rural community (mean $=3.35$ ). This is an important aspect for assuring sustainable development of the rural area.

Tourism is perceived as a factor that influences the development of the traffic network (mean $=3.06$ ) and of the living utilities (mean $=3.19$ ) and improves the quality of public services (mean $=3.33$ ). Improvement in the quality of public services is a result of higher standards of the tourists who visit the area. Therefore, in order to satisfy the tourists' expectations, the services are adapted to their needs and quality standards are imposed.

\subsection{Local Residents' Support for Future Tourism Development}

Principal component analysis was used to assess the reliability of the 8 variables related to future sustainable tourism development. The Barlett test of sphericity is significant (Chi-square $=1026.348$, $p<0.000)$. The Kaiser-Meyer-Olkin $(\mathrm{KMO})$ overall measure of sampling is 0.84 , indicating that data are suitable for the principal component analysis [52]. The PCA with varimax rotation of the 8 variables resulted in a two-component solution that explains $56.67 \%$ of the total variance. The overall reliability of the 8 variables is 0.83 .

Four attitude variables ("plans are important to manage the growth of tourism," "long-term planning reduces the negative environmental impact," "authorities support tourism development," and "new environment protection measures") concerning the sustainable development of tourism were loaded in the first component with the cross-correlation coefficients of $0.820,0.751,0.747$ and 0.703 . This factor accounts for $42.89 \%$ of the total variance and was named support for tourism sustainable development (Table 5). The higher scores indicate that rural residents are focused on the long-term impact of tourism development.

The second component consists of 4 variables ("tourism represents a sustainable activity," "support for new facilities," "my community should become a tourist destination" and "tourism should become an important part of the community") with the cross-correlation coefficients of 0.756 , $0.740,0.665$ and 0.514 (Table 5). This factor accounts $13.78 \%$ of the total variance and was termed support for tourism destination development. 
Table 5. Support for future tourism development.

\begin{tabular}{|c|c|c|c|c|c|}
\hline Eigenvalue & Variance \% & Component & Items & $\begin{array}{c}\text { Factor } \\
\text { Loading }\end{array}$ & Communalities \\
\hline \multirow{4}{*}{3.43} & \multirow{4}{*}{42.89} & \multirow{4}{*}{$\begin{array}{c}\text { Sustainable } \\
\text { development } \\
\alpha=0.77\end{array}$} & $\begin{array}{l}\text { It is important to develop plans to manage } \\
\text { the growth of tourism }\end{array}$ & 0.820 & 0.717 \\
\hline & & & $\begin{array}{l}\text { Long-term planning will reduce the negative } \\
\text { environmental impacts }\end{array}$ & 0.751 & 0.565 \\
\hline & & & $\begin{array}{l}\text { I agree that local authorities support } \\
\text { tourism development }\end{array}$ & 0.747 & 0.625 \\
\hline & & & $\begin{array}{l}\text { New environment protection measures } \\
\text { should be developed }\end{array}$ & 0.703 & 0.544 \\
\hline \multirow{4}{*}{1.10} & \multirow{4}{*}{13.78} & \multirow{4}{*}{$\begin{array}{l}\text { Tourism } \\
\text { destination } \\
\alpha=0.61\end{array}$} & $\begin{array}{l}\text { Tourism is a sustainable activity in } \\
\text { my community }\end{array}$ & 0.756 & 0.580 \\
\hline & & & I support new tourism facilities & 0.740 & 0.617 \\
\hline & & & $\begin{array}{l}\text { My community should become more of } \\
\text { a tourist destination }\end{array}$ & 0.665 & 0.617 \\
\hline & & & $\begin{array}{l}\text { I support tourism and I would like to see it } \\
\text { become an important part of my community }\end{array}$ & 0.514 & 0.270 \\
\hline $\begin{array}{c}\text { Total } \\
\text { variance } \%\end{array}$ & 56.67 & & & & \\
\hline
\end{tabular}

The development of tourism should be supported by the local authorities (mean $=4.35$ ) by setting strategic plans, with clear actions for tourism's growth management (mean $=4.11)$. The long-term planning with reduction of negative environmental impacts (mean $=3.76)$ and new environmental protection measures (mean $=3.95$ ) are less supported than the involvement of local authorities and strategic planning of tourism development because of the reduced negative impact of tourism on the environment, as was noticed in Section 4.3.

The rural residents believe that tourism should be encouraged and become an important part of the community (mean $=4.12)$. This can be achieved by developing new tourism facilities $($ mean $=4.32)$ that will assure job alternatives for the local community. Furthermore, development plans should take into consideration the desire of the local residents for the sustainable development of their region as a tourism destination $($ mean $=4.12)($ Table 6$)$.

Table 6. Degree of agreement for future tourism development.

\begin{tabular}{lcc}
\hline \multicolumn{1}{c}{ Statements } & Mean & SD \\
\hline Sustainable development & 4.03 & 0.961 \\
It is important to develop plans to manage the growth of tourism & 4.11 & 1.196 \\
Long-term planning will reduce the negative environmental impacts & 3.76 & 1.273 \\
I agree that local authorities support tourism development & 4.35 & 1.111 \\
New environment protection measures should be developed & 3.95 & 1.331 \\
Destination development & 4.24 & 0.820 \\
I support new tourism facilities & 4.32 & 0.994 \\
Tourism is a sustainable activity in my community & 4.12 & 1.134 \\
My community should become more of a tourist destination & 4.12 & 1.118 \\
I support tourism and I would like to see it become an important part of my community & 4.49 & 1.678 \\
\hline
\end{tabular}

The results of simple correlation analysis on the support for sustainable tourism development and support for destination development for environmental impacts, economic benefits, socio-cultural impacts, infrastructure benefits, and age are listed in Table 7. The environmental impact $(r=-0.214$, $p<0.01)$, economic benefits $(r=0.230, p<0.01)$, socio-cultural impacts $(r=0.498, p<0.01)$ and infrastructure benefits $(r=0.328, p<0.01)$ were significantly correlated with support for sustainable development. The environmental impact $(r=-0.252, p<0.01)$, economic benefits $(r=0.241, p<0.01)$, socio-cultural impacts $(r=0.418, p<0.01)$, and infrastructure benefits $(r=0.292, p<0.01)$ were 
significantly correlated with support for future tourism destination development. Age does not have any influence on the residents' support for tourism development (Table 7). A $t$-Test was carried out to examine the influence of gender and education level on the support for future tourism development (Tables 8 and 9).

Table 7. Correlation of each variable with the support for sustainable development and destination development.

\begin{tabular}{lcccc}
\hline \multicolumn{1}{c}{ Dependent Variable } & \multicolumn{2}{c}{ Sustainable Development } & \multicolumn{2}{c}{ Destination Development } \\
\hline \multicolumn{1}{c}{ Independent Variable } & Correlation Coefficient $(\boldsymbol{r})$ & $\boldsymbol{p}$-Value & Correlation Coefficient $(\boldsymbol{r})$ & $\boldsymbol{p}$-Value \\
\hline Environment impact & $-0.214^{* *}$ & 0.000 & $-0.252^{* *}$ & 0.000 \\
Economic benefits & $0.230^{* *}$ & 0.000 & $0.241^{* *}$ & 0.000 \\
Social and cultural impacts & $0.498^{* *}$ & 0.000 & $0.418^{* *}$ & 0.000 \\
Infrastructure & $0.328^{* *}$ & 0.000 & $0.292^{* *}$ & 0.000 \\
Age & $-0.036^{*}$ & 0.457 & -0.052 & 0.282 \\
\hline
\end{tabular}

${ }^{*}$ significant at $0.05 ;{ }^{* *}$ significant at 0.01 .

Table 8. Results of t-test analysis of gender and support for future tourism development.

\begin{tabular}{ccccc}
\hline \multirow{2}{*}{ Dependent Variable } & \multicolumn{2}{c}{ Means } & \multirow{2}{*}{ Value } & \multirow{2}{*}{ Sig. } \\
\cline { 2 - 4 } & Female & Male & & \\
\hline Sustainable development & 4.17 & 3.94 & 2.545 & $0.013^{*}$ \\
Destination development & 4.34 & 4.18 & 2.017 & $0.044^{*}$ \\
\hline \multicolumn{6}{c}{ * significant at $0.05 ;{ }^{* *}$ significant at 0.01.} \\
\end{tabular}

Table 9. Results of t-test analysis of education level and support for future tourism development.

\begin{tabular}{|c|c|c|c|c|}
\hline \multirow{2}{*}{ Dependent Variable } & \multicolumn{2}{|c|}{ Means } & \multirow{2}{*}{$t$ Value } & \multirow{2}{*}{ Sig. } \\
\hline & Less than High School & More than High School & & \\
\hline Sustainable development & 3.91 & 4.08 & -1.696 & 0.091 \\
\hline Destination development & 4.14 & 4.29 & -1.715 & 0.087 \\
\hline
\end{tabular}

There is an indirect link between perceived environmental impact and the support for sustainable development, and between environmental impact and support for tourism destination development. A direct link can be observed between economic impact, social and cultural impact, infrastructure benefits and the support of local community for future tourism development (Table 7).

Residents who perceive the impact of tourism less negatively tend to more highly support sustainable tourism development in the rural area. Referring to Table 8, the results show that females differ significantly in their support for tourism development (mean $=4.17$ for sustainable development and mean $=4.34$ for destination development). This can be explained by the fact that tourism represents an alternative activity for agriculture in the rural space, which can attract young people to establish themselves and work in the rural area. Furthermore, tourism represents a source of employment and entrepreneurial opportunities for women [57]. Results showed that residents who perceive the environmental impact of tourism more negatively tend to display diminished support for the future development of tourism, as was also suggested in previous studies $[5,44]$.

Economic and socio-cultural benefits can be considered personal benefits of tourism development. The greater the benefits the rural residents perceive from tourism, the more likely they are to support sustainable tourism development, and the more likely they are to transform their community into 
a tourism destination. The findings support past studies regarding residents' support of tourism development, which found that the higher the personal benefits from tourism are, the more willing the local residents are to develop tourism in their community [28,33].

\section{Conclusions}

The research objectives were to investigate rural residents' attitudes towards various tourism impact variables and to explore their influence on the support of future sustainable tourism development. The results of this research indicate that rural residents perceive tourism development positively. Tourism is a sustainable development activity in the rural community. The environmental component of sustainable development is the most important one, a fact that can be explained by the high natural tourist potential and the awareness of the local residents of the importance of natural conservation for sustainable development, on the one hand, and the desire to reduce the negative effects of tourism development on the area on the other.

Tourism development improves the quality of life of local residents due to its effect on economic development of the area, which in turn leads to new employment opportunities. Furthermore, tourist activity in the rural area is perceived as being beneficial to the diversification of recreational alternatives and the improvement of the general infrastructure. Similar findings in examination of residents' attitudes toward tourism development were observed by Abdollahzadeh and Sharifzadeh [46].

Results indicate that tourism impacts are perceived positively as employment opportunity and well-being increases. An important segment of the rural population is willing to support the development of sustainable tourism because of the personal benefits obtained in terms of socio-cultural aspects (arts and crafts development, improvement of social life and facilities).

The results show that rural residents see tourism as an income generator, but at the same time they understand the importance of planning and managing tourism destinations sustainably. The local community, as an important stakeholder within the tourism sector, becomes a key element in developing future tourism strategies. Hanafiah [47] underlined that the community should get actively involved in the process of tourism development.

For rural residents, tourism is seen as an opportunity to enhance the wellbeing of the community in general, and particularly their own. The local community is willing to support sustainable tourism development if the personal benefits perceived are important. The greater the perceived economical, socio-cultural and infrastructure benefits, the higher the support is from the local community in building future tourism strategies.

This study revealed a lack of knowledge regarding residents' perceptions towards tourism impact and attitudes toward sustainable tourism development in a rural area of Romania. The results provide tourism planners and policymakers with viable information regarding rural residents' attitudes toward the development of tourism, which can serve as a useful tool in future development plans, enhancing sustainable tourism development and reducing tourism's negative impacts. Even if at the moment the residents tend to support sustainable tourism development, it is recommended that long-term changes in residents' attitudes and perceptions be taken into account. Furthermore, it was shown that the support for sustainable tourism development is greater if policymakers and tourism planners are attentive to residents' concerns and beliefs [28].

Over time, a lack of consistent and reliable information regarding local residents' attitudes towards sustainable rural development has negatively influenced the decision-making process regarding the sector's funding allocation. In fact, The National Rural Development Plan 2014-2020 of Romania includes two different specific measures indirectly related to rural tourism: Measure 06- “Development of exploitations and companies" (Under-measure 6.4 "Support for investments in creating and developing non-agricultural activities"), and Measure 07-“Basic services and village renewal in rural areas" (Under-measure 7.6 "Investments related to cultural heritage protection") [58]. No specific measure was dedicated to rural tourism during this period. In the first two years of implementation (2014 and 2015), 52 proposals were submitted (75,987,178 Euro) under Under-measure 
6.4, while only 2 were accepted and financed (350,858 Euro), and none were financed in the first two years. Concerning Under-measure 7.6, 224 proposals were submitted (42,565,798 Euro), and not one was accepted and financed until the end of 2015 [59]. The results of this research can contribute to an improved strategy regarding rural tourism development, such as considering residents' requirements and expectations when creating the specifications of the under-measures, a process that would result in more sustainable rural tourism development.

Finally, this study has several limitations: primarily, limited time and low budget. Like its predecessors [27], this study did not clarify how the residents perceive themselves as benefiting from sustainable tourism development. Due to the variety of natural and anthropic tourism potential at this moment, based on the results of the research, it is impossible to formulate specific recommendations for different types of tourism products. Furthermore, the studies that follow should focus more on the particularities of the natural characteristics of the research area (thermal water, natural parks proximity, etc.), while more factors influencing the support for sustainable tourism development should be added (field of activity, land ownership, dependence on tourism, preoccupation for nature protection and responsible behavior) to determine the support for sustainable tourism development. In this way, important information can be gained and geared towards specific actions for future tourism development.

Acknowledgments: Assistance provided by Molly McDonough, graduate of Master Food Identity, during the writing and English-proofing of the manuscript is greatly appreciated.

Author Contributions: Iulia C. Muresan, Rezhen Harun and Felix H. Arion designed the research; Camelia F. Oroian, Alexandru Todea and Ramona Lile applied the survey; Camelia F. Oroian and Andra Porutiu organized the data based; Iulia C. Muresan and Gabriela O. Chiciudean analyzed the data, Iulia C. Muresan, Gabriela O. Chiciudean, Felix H. Arion and Rezhen Harun wrote the manuscript.

Conflicts of Interest: The authors declare no conflict of interest.

\section{References}

1. Egbali, N.; Nosrat, A.B.; Alipour, S.K.S. Effects of positive and negative rural tourism (Case study: Rural Semnan Province). J. Geogr. Reg. Plan. 2011, 4, 63-76.

2. Shariff, N.M.; Abidin, A.Z. Community attitude towards tourism impacts: Developing a standard instrument in the Malaysian context. E-J. Soc. Sci. Res. 2013, 1, 386-396.

3. Eraqi, M.I. Local communities' attitudes towards impacts of tourism development in Egypt. Tour. Anal. 2007, 12, 191-200. [CrossRef]

4. Budeanu, A. Impacts and responsibilities for sustainable tourism: A tour operator's perspective. J. Clean. Product. 2005, 13, 89-97. [CrossRef]

5. Ramseook-Munhurrun, P.; Naidoo, P. Residents' attitudes toward perceived tourism benefits. Int. J. Manag. Mark. Res. 2011, 4, 45-56.

6. Eshliki, S.A.; Kaboudi, M. Perception of community in tourism impacts and their participation in tourism planning: Ramsar, Iran. J. Asian Behav. Stud. 2012, 2, 51-64. [CrossRef]

7. Stetic, S. Specific features of rural tourism destinations management. J. Settl. Spat. Plan. 2012, 1, 131-137.

8. De la Torre, G.M.V.; Gutiérrez, E.M.A.; Guzman, T.J.L.G. Tourism as generator of wealth in rural areas. In Proceedings of the 18th European Advanced Studies Institute in Regional Science, Lodz-Cracow, Poland, 1-10 July 2005.

9. Giannakis, E. The role of rural tourism on the development of rural areas: The case of Cyprus Elias. Romanian J. Reg. Sci. 2014, 8, 38-53.

10. Garau, C. Perspectives on cultural and sustainable rural tourism in a smart region: The case study of Marmilla in Sardinia (Italy). Sustainability 2015, 7, 6412-6434. [CrossRef]

11. Iunius, R.F.; Cismaru, L.D. Raising competitiveness for tourist destinations through information technologies within the newest tourism action framework proposed by the European commission. Sustainability 2015, 7, 12891-12909. [CrossRef]

12. Mihalic, T. Sustainable-responsible tourism discourse e towards 'responsustable' tourism sustainability. J. Clean. Prod. 2014. [CrossRef] 
13. Turnock, D. Sustainable rural tourism in the Romanian Charpatians. Geogr. J. 1999, 165, 192-199. [CrossRef]

14. Dragulanescu, I.V.; Drutu (Ivan), M. Rural tourism for local economic development. Int. J. Acad. Res. Account. Financ. Manag. Sci. 2012, 2, 196-203.

15. Iorio, M.; Corsale, A. Rural tourism and livelihood strategies in Romania. J. Rural Stud. 2010, 26, $152-162$. [CrossRef]

16. Negrusa, A.L.; Cosma, S.A.; Bota, M. Romanian rural tourism development: A study case in Maramures. Int. J. Bus. Res. 2007, 7, 129-135.

17. Marin, D.; Petroman, C.; Petroman, I.; Ciolac, R.; Balan, I. Study regarding rural guest-house and agritourist household's number and percent in the total number of tourists establishments in Romania. Lucr. Stiintifice Ser. Agron. 2009, 52, 469-470.

18. Arion, F.; Muresan, I. An overview of rural tourism in the development regions of Romania. Bull. UASVM Hortic. 2008, 62, 35-40.

19. Naghiu, A.; Vasquez, J.L.; Georgiev, I. Rural development strategies through rural tourism activities in Romania: Chance for an international demand? Int. Rev. Public Nonprofit Mark. 2005, 2, 85-95. [CrossRef]

20. Vanhove, N. The Economics of Tourism Destination; Elsevier Butterworth-Heinemann: Oxford, UK, 2005.

21. Mansfeld, Y.; Jonas, A. Evaluating the socio-cultural carrying capacity of rural tourism communities: A 'value stretch' approach. Tijdschr. Voor Econ. Soc. Geogr. 2006, 97, 583-601. [CrossRef]

22. Min, Z.; Xiaoli, P.; Bihu, W. Research on residents' perceptions on tourism impacts and attitudes: A case study of Pingyao ancient city. In Proceedings of the 6th Conference of the International Forum on Urbanism (IFoU), Tourbanism, Barcelona, 25-27 January 2012; pp. 1-10.

23. Mohammadi, M.; Khalifah, Z.; Hosseini, H. Local people perceptions toward social, economic and environmental impacts of tourism in Kermanshah (Iran). Asian Soc. Sci. 2010, 6, 220-225. [CrossRef]

24. Banki, M.B.; Ismail, H.N. Multi-stakeholder perception of tourism impacts and ways tourism should be sustainably developed in obudu mountain resort. Dev. Ctry. Stud. 2014, 4, 37-48.

25. Huh, C.; Vogt, C.A. Changes in residents' attitudes toward tourism over time: A cohort analytical approach. J. Travel Res. 2008, 46, 446-455. [CrossRef]

26. Bestard, A.B.; Nadal, R.J. Attitudes toward tourism and tourism congestion. Reg. Dev. 2007, 25, $193-207$.

27. McGehee, N.G.; Andereck, K.L. Factors predicting rural residents' support of tourism. J. Travel Res. 2004, 43, 131-140. [CrossRef]

28. Long, P.H. Perceptions of tourism impact and tourism development among residents of Cuc Phuong National Park, Ninh Binh, Vietnam. J. Ritsumeikan Soc. Sci. Hum. 2011, 3, 75-92.

29. Ko, D.W.; Stewart, W.P. A structural equation model of residents' attitudes for tourism development. Tour. Manag. 2002, 23, 521-530. [CrossRef]

30. Brida, J.G.; Disegna, M.; Osti, L. Residents' perceptions of tourism impacts and attitudes towards tourism policies in a small mountain community. In Proceedings of the Ninth Canadian Congress on Leisure Research, Wolfville, NS, Canada, 12-15 May 1999.

31. Choi, H.C.; Murray, I. Resident attitudes toward sustainable community tourism. J. Sustain. Tour. 2010, 18, 575-594. [CrossRef]

32. Lepp, A. Residents' attitudes towards tourism in Bigodi village, Uganda Case study. Tour. Manag. 2007, 28, 876-885. [CrossRef]

33. Wang, Y.; Pfister, R.E. Residents attitudes toward tourism and perceived personal benefits in a rural community. J. Travel Res. 2008, 47, 84-93. [CrossRef]

34. Lee, T.H. Influence analysis of community resident support for sustainable tourism development. Tour. Manag. 2013, 34, 37-46. [CrossRef]

35. Stylidis, D.; Biran, A.; Sit, J.; Szivas, E.M. Residents' support for tourism development: The role of residents' place image and perceived tourism impacts. Tour. Manag. 2014, 45, 260-274. [CrossRef]

36. Agenţia de Dezvoltare Regională Nord-Vest. Prezentarea Regiunii Nord-Vest (Transilvania de Nord). Available online: http://www.nord-vest.ro/DESPRE-NOIAgentia-de-Dezvoltare-Regionala-Nord-Vest/ REGIUNEA-TRANSILVANIA-DE-NORD/Prezentare-Regiune.html (accessed on 1 November 2015). (In Romanian).

37. The Convention on Biological Diversity. Regiunea Nord-Vest (Cluj-Napoca). Available online: http:/ / biodiversitate.mmediu.ro/romanian-biodiversity/despre-arii-protejate/arpm/regiunea-nord-vestcluj-napoca/ (accessed on 1 November 2015). (In Romanian). 
38. Dumitraş, D.; Pop, A. Perspective on the management of Rodna Mountains National Park. Bull. UASVM Hortic. 2009, 66, 164-169.

39. Dumitras, D.E.; Muresan, I.C.; Ilea, M.; Jitea, I.M. Agritourism-A potential linkage between local communities and parks to maintain sustainability. Bull. UASVM Hortic. 2013, 70, 300-309.

40. EY, Building a Better Working World. Entrepreneurs Speak Out. Entrepreneurship Barometer Romania 2013. Available online: http://www.ey.com/Publication/vwLUAssets/EY_Entrepreneurs_Speak_Out_survey_13 _Feb_2014_(EN)/\$FILE/EY\%20Entrepreneurship\%20Barometer\%20Romania\%202013.pdf (accessed on 30 December 2015).

41. Muresan, I.C.; Arion, F.H.; Harun, R. Study regarding rural guesthouse and tourists' satisfaction. Bull. UASMV Hortic. 2013, 70, 362-367.

42. Ioan, I.; Radulescu, C.V.; Bran, F. Romanian rural tourism: Status and prospects by innovative organizational approaches. J. Tour. Stud. Res. Tour. 2014, 17, 15-21.

43. National Institute of Statistics, Tempo-Online Time Series. Available online: http://statistici.insse.ro/ shop/?lang=en (accessed on 25 October 2015).

44. Teye, V.; Sonmez, S.F.; Sirakaya, E. Residents' attitudes toward tourism development. Ann. Tour. Res. 2002, 29, 668-688. [CrossRef]

45. Brida, J.G.; Disenga, M.; Osti, L. Residents' perception and attitudes towards tourism impacts: A case study of the small rural community of Folgaria (Trentino-Italy). Int. J. 2011, 18, 359-385.

46. Abdollahzadeh, G.; Sharifzaden, A. Rural residents' perception toward tourism development: A study from Iran. Int. J. Tourism Res. 2014, 16, 126-136. [CrossRef]

47. Hanafiah, M.H.; Jamaluddin, M.R.; Zulkifly, M.I. Local community attitude and support towards tourism development in Tioman Island, Malaysia. Procedia Soc. Behav. Sci. 2013, 105, 792-800. [CrossRef]

48. Wang, Y.; Pfister, R.E.; Duarte, B. Residents' attitudes toward tourism development: A case study of Washington, NC. In Proceedings of the North-Eastern Recreation Research Symposium, Bolton Landing, NY, USA, 9-11 April 2006; pp. 411-418.

49. Costello, A.B.; Osborne, J.W. Best practices in exploratory factor analysis: Four recommendations for getting the most from your analysis. Pract. Assess. Res. Eval. 2005, 10, 1-9.

50. Jollitte, I.T. Principal Component Analysis; Springer Science + Business Media: New York, NY, USA, 2014.

51. Ding, C.; He, X. K-means clustering via principal component analysis. In Proceedings of the 21st International Conference on Machine Learning, Banff, AB, Canada, 4-8 July 2004; pp. 29-37.

52. Kaiser, H.F. Index of factorial simplicity. Psychometrika 1974, 39, 31-36. [CrossRef]

53. Tabachinick, B.G.; Fidell, L.S. Using Multivariate Statistics, 2nd ed.; Harper \& Row: Cambridge, UK, 1989.

54. Hair, J.F.; Anderson, R.E.; Tatham, R.L.; Black, W.C. Multivariate Data Analysis, 5th ed.; Prentice Hall: Upper Saddle River, NJ, USA, 1998.

55. Burgess, S.M.; Steenkamp, J.B.E.M. Marketing renaissance: How to research in emerging markets advances marketing science and practice. Int. J. Res. Mark. 2006, 23, 337-356. [CrossRef]

56. Nunnally, J.; Bernstein, I. Psychometric Theory, 3rd ed.; McGraw-Hill: New York, NY, USA, 1994.

57. Figueroa-Domecq, C.; Pritchard, A.; Segovia-Perez, M.; Morgan, N.; Villace-Molinero, T. Tourism gender research: A critical accounting. Ann. Tour. Res. 2015, 52, 87-103. [CrossRef]

58. Ministry of Agriculture and Rural Development in Romania. Programul National de Dezvoltare Rurală pentru perioada 2014-2020. Available online: http:/ / www.madr.ro/docs/dezvoltare-rurala/programare2014-2020/PNDR_2014_-_2020_01.07.2014.pdf (accessed on 22 December 2015). (In Romanian).

59. Ministry of Agriculture and Rural Development in Romania. Situatia proiectelor depuse in cadrul PNDR 2014-2020 la data de 31.12.2015 conform registului electronic al ceririlor de finanţare. Available online: http:/ / www.madr.ro/pndr-2014-2020/implementare-pndr-2014-2020/situatia-proiectelor-depuse-20142020/download/1816_7595b8fd510ac8d1f2b3cfd18932f357.html (accessed on 19 January 2016). (In Romanian).

(C) 2016 by the authors; licensee MDPI, Basel, Switzerland. This article is an open access article distributed under the terms and conditions of the Creative Commons by Attribution (CC-BY) license (http://creativecommons.org/licenses/by/4.0/). 